\title{
ОСОБЛИВОСТІ ПРОФЕСІЙНОЇ ПІДГОТОВКИ МЕДИЧНИХ СЕСТЕР НА СУЧАСНОМУ ЕТАПІ
}

\author{
ДВНЗ «Тернопільський державний медичний університет \\ імені І.Я. Горбачевського МОЗ України», м. Тернопіль, Україна
}

\begin{abstract}
Мета: висвітлити роль медичних сестер у сучасній системі охорони здоров'я та обґрунтувати шляхи поліпшення їх профресійної підготовки.

Матеріали і методи. У дослідженні використано бібліосемантичний та аналітичний методи.

Результати. У статті викладено сучасні дані щодо профресійних та етичних якостей медичної сестри, реформи медсестринства на сучасному етапі та нових компетенцій в роботі середнього медичного персоналу.

Висновки. Без докорінного перегляду всієї програми підготовки та перепідготовки орахівців сестринської справи, без впровадження нових технологій організації сестринської допомоги, матеріальної та правової підтримки медичних сестер подальше вдосконалення системи охорони здоров'я просто не можливе.
\end{abstract}

КЛЮчОВІ СЛОВА: освіта; медична сестра; реформування.

Рефрормування охорони здоров'я в Україні належить до пріоритетних завдань внутрішньої політики. Держава визначає здоров'я населення однією 3 найбільших цінностей, необхідним компонентом розвитку та соціально-економічного процвітання України [1]. Сьогодні зростає роль медсестринських служб та медичної сестри як фрахівця, яка першою контактує $з$ пацієнтом, його родиною та оточенням і опікується ними в лікарні та вдома до кінця життя. За таких умов зростає і актуальність профресійної підготовки медичних сестер, що випливає 3 визначення поняття «медична сестра», запропонованого Міжнародною радою медичних сестер: «Медична сестра - це особа, яка пройшла підготовку за основною програмою медсестринського навчання, одержала достатню кваліфрікацію і має право виконувати в своїй країні відповідальну роботу з медсестринського обслуговування, маючи на меті зміцнення здоров'я, запобігання хворобам та здійснення догляду за хворими» [2].

Мета роботи: висвітлити роль медичних сестер у сучасній системі охорони здоров'я та обґрунтувати шляхи поліпшення їх професійної підготовки.

Матеріали і методи. У дослідженні використано бібліосемантичний та аналітичний методи.

Результати дослідження та їх обговорення. На сучасному етапі перетворень в освіті України, спрямування ії до європейських стандартів, загострюється проблема підвищення якості змісту підготовки фрахівців медичної галузі. Медична освіта за своїм призначенням здійснює професійну підготовку компетентного фрахівця, спроможного як забезпечувати надання належних медичних послуг, так і покращувати рівень якості охорони здоров'я загалом [3].

Нове освітнє середовище має забезпечувати умови для фрормування медсестри, яка гармонійно вписуватиметься в нові умови праці та структуру рефрормованої галузі охорони здоров'я. Навчання повинно базуватися на основі особистісної зацікавленості медсестри, що сприятиме фрормуванню іiі пізнавальної активності на основі потенційних інтересів. В основі інноваційних методів навчання повинні бути методики, що розвиватимуть системне, а то й інтуїтивне мислення, вміння знаходити, фрільтрувати та систематизувати інформацію [4].

Метою професійної підготовки нині $€$ фрормування компетентних фрахівців, які можуть максимально втілювати свій потенціал у певній галузі трудової діяльності. За даними М. Бабича, основною метою підготовки молодшого медичного спеціаліста $€$ фрормування фрахівця нового зразка, в центрі професійної діяльності якого є особистість 3 її особливостями, індивідуальним станом здоров'я та внутрішніми потенційними можливостями до адаптації; фрахівця, діяльність якого зосереджена на творчу, діалогічну, емпатійну взаємодію 3 пацієнтом, на активізацію потенційних можливостей особистості, поліпшення і гармонізацію індивідуальних компенсаторних резервів; фахівця, спроможного ефективно здійснювати належний догляд за хворими, встановлювати медсестринський діагноз, визначати проблеми пацієнта, виконувати призначення лікаря в амбулаторних і стаціонарних умовах, в умовах сім'ї, в освітніх закладах [5]. 
Медичний працівник середньої ланки нині $\epsilon$ партнером лікаря і виконує багато самостійних функцій. Він збирає інформацію про хворого, вивчає його потреби й проблеми, планує та реалізовує план лікування пацієнтів певних груп, відповідно, консультуючись 3 лікарем, ставить до відома лікаря про зміни у здоров'ї хворого; спільно $з$ лікарем бере участь в обходах, реалізовує його призначення не лише щодо діагностичних, а й лікувальних заходів, здатний діяти незалежно, та в співпраці з іншими фахівцями галузі охорони здоров'я [6].

Варто відзначити такі компетенції медичного працівника, які $є$ важливими для здійснення професійного самовдосконалення: усвідомлення та сприйняття морально-етичних норм поведінки стосовно колег, пацієнтів, оточуючого середовища (принцип біоетики); володіння та дотримання норм здорового способу життя; потреба вчитися; здатність до об'єктивної критики і самокритики; адаптивність і комунікабельність; наполегливість у досягненні мети; знання іноземної мови; навички роботи з комп'ютерними технологіями; уміння збирати, аналізувати й керувати інфрормацією; дослідницькі навички [7].

Сучасна клінічна практика потребує фрахівців, які володіють новітніми технологіями здійснення догляду за хворими, та надання відповідних медичних послуг згідно з існуючими європейськими вимогами. Це потребує від медичних працівників готовності до постійного професійного самовдосконалення. Таку готовність потрібно фрормувати в студентів ще під час їхнього навчання в медичному навчальному закладі, який, за словами Т. Комщук, $€$ тим соціумом, що спрямований на створення есрективних умов для самовдосконалення, самореалізації та саморозвитку особистості [8].

Л. В. Задирака також наголошує, що дуже важливо, щоб саме у процесі навчання в навчальному закладі прищеплювали такі якості, як співробітництво, самостійність і прагнення до самореалізації при вирішенні профресійно-орієнтованих завдань. Якщо робота всіх учасників процесу творча, професійна, то в досягненні поставленої мети й успіху можна не сумніватися. На даний час основне завдання будь-якого навчального закладу - не стільки передати знання студентам, скільки навчити самостійно опрацьовувати матеріал, спрямувати студента на самонавчання, саморозвиток і самореалізацію у власній професійній діяльності [9].

Крім того, перехід на нові принципи сестринської роботи вимагає розробки нормативно-законодавчої бази, що визначає галузь професійної компетенції та включає нові переліки посадових обов'язків, нові навчально-методичні матеріали, нові стандарти сестринської роботи. Тим часом досі відсутній закон, який регламентує діяльність медичної сестри, перелік прав і обов'язків та соціальний статус.

Отже, сучасні тенденції розвитку вітчизняної системи охорони здоров'я диктують необхідність розширення і правового закріплення змісту профресійної діяльності спеціалістів із середньою медичною освітою. 3 кожним роком зростає внесок даної профресійної групи медичних працівників у справу охорони здоров'я населення, більш глибоко усвідомлюється необхідність подальшого розвитку функцій професійної діяльності сестринського персоналу. Найважливішим критерієм цінності медичної сестри-керівника є її управлінська компетентність, лідерські якості, комунікативні здібності, оптимізм ведення майбутнього і бажання знати те, що не знаєш сьогодні.

\section{Висновки}

Соціально-економічні та соціально-психологічні зміни в суспільстві, розвиток нових технологій в охороні здоров'я, високі вимоги до якості діяльності медичної сестри привели до необхідності вдосконалення сестринської справи, включно підготовку висококваліфікованих кадрів та їх раціональне використання. Без докорінного перегляду всієї програми підготовки та перепідготовки фрахівців сестринської справи, без впровадження нових технологій організації сестринської допомоги, матеріальної та правової підтримки медичних сестер подальше вдосконалення системи охорони здоров'я просто не можливе, що і стане перспективою наших подальших досліджень.

\section{Список літератури}

1. Концепція розвитку системи громадського здоров'я в Україні [Електронний ресурс]. - 2016. - Режим доступу : http://moz.gov.ua/doc3/4 les/Pro_20160309_0_dod.pdf.

2. Опыт организации контроля качества сестринской деятельности в терапевтическом стационаре / В. В. Масляков, В. А. Левина, И. В. Романова, Н. М. Нехотящая // Фундаментальные исследования. - 2013. - № 9-3. - С. 404-408. 3. Дудікова Л. В. Формування готовності до професійного самовдосконалення у майбутніх лікарів : автореф. дис. на здобуття наук. ступеня канд. пед. наук : спец. 13.00.04 «Теорія і методика професійної освіти» / Л. В. Дудікова. - Вінниця, 2011. - 20 с.

4. Романішена-Лановська Л. К. Інноваційні методи в післядипломній підготовці медсестри / Л. К. РоманішенаЛановська, О. Н. Литвинова, С. О. Ястремська // Медсестринство. - 2016. - № 4. - С. 5-7.

5. Бабич М. Я. Формування професійних якостей майбутнього молодшого медичного спеціаліста як психологічна проблема / М. Я. Бабич // Актуальні питання теорії та практики психолого-педагогічної підготовки фрахівців за соціономічним профрілем : матеріали наук.-практ. конфр. - Хмельницький : ХНУ, 2011. - С. 102-103. 
6. Кравченко О. Гуманізація навчально-виховного середовища медичного коледжу як основа фрормування профресійної етики майбутніх медичних сестер / О. Кравченко // Освіта дорослих: теорія, досвід, перспективи : зб. наук. пр. - К. : видавець ПП Лисенко М. М., 2012. - Вип. 4. - С. 147-154.

7. Визначено стратегію розвитку медичної освіти в Україні [Електронний ресурс] // Урядовий портал. 08.12.2005. Прес-служба МОЗ України. - Режим доступу : http://www.kmu.gov.ua/control/publish/article?art_id =25537906.

8. Комщук Т. С. Етичні основи сестринської справи / Т. С. Комщук // Медсестринство. - 2009. - № 2. - С. 25-27.

9. Задирака Л. В. Особливості розвитку професійно важливих психологічних якостей майбутніх медичних сестер / Л. В. Задирака // Медсестринство. - 2016. - № 3. - С. 19-22.

\title{
References
}

1. Kontseptsiia rozvytku systemy hromadskoho zdorovia v Ukraini [Concepts of the development of health care system in Ukraine]. (2016). moz.gov.ua. [in Ukrainian]. Retrieved from: http://moz.gov.ua/doc3/4 les/Pro_20160309_0_dod.pdf 2. Maslyakov, V.V., Levina, V.A., Romanova, I.V., \& Negotyashchaya, N.M. (2013). Opyt organizatsii kontrolya kachestva sestrinskoy deyatelnosti $v$ terapevticheskom statsionare [Experience in the organization of quality control of nursing activity in a therapeutic hospital]. Fundamentalnye issledovaniya - Basic Research, 9, 3, 404-408 [in Russian].

3. Dudikova, L.V. (2011). Formuvannia hotovnosti do profesiinoho samovdoskonalennia u maibutnikh likariv [Formation of readiness for professional self-improvement of future doctors]. Extended abstract of Candidate's thesis. Vinnytsia [in Ukrainian].

4. Romanishena-Lanovska, L.K., Lytvynova, O.N., \& Yastremska, S.O. (2016). Innovatsiini metody v pisliadyplomnii pidhotovtsi medsestry [Innovative methods in postgraduate nursing training]. Medsestrynstvo - Nursing, 4, 5-7 [in Ukrainian].

5. Babych, M.la. (2011). Formuvannia profesiinykh yakostei maibutnoho molodshoho medychnoho spetsialista yak psykholohichna problema [Formation of professional qualities of the future junior medical specialist as a psychological problem]. Aktualni pytannia teorii ta praktyky psykholoho-pedahohichnoi pidhotovky fakhivtsiv za sotsionomichnym profilem]. Materialy nauk.-prakt. konf. - Proceedings of Scientific and Practical Conference. Khmelnytskyi: KhNU [in Ukrainian].

6. Kravchenko, O. (2012). Humanizatsiia navchalno-vykhovnoho seredovyshcha medychnoho koledzhu yak osnova formuvannia profesiinoi etyky maibutnikh medychnykh sester [Humanization of the educational environment of the medical college as the basis for the formation of the professional ethics of future nurses]. Osvita doroslykh: teoriia, dosvid, perspektyvy: zb. nauk. pr. Kyiv: PP Lysenko M.M. [in Ukrainian].

7. Vyznacheno stratehiiu rozvytku medychnoi osvity $v$ Ukraini [The strategy of medical education development in Ukraine is determined]. (2005). www.kmu.gov.ua. Retrieved from: http://www.kmu.gov.ua/control/publish/article?art_id =25537906. 8. Komshchuk, T.S. (2009). Etychni osnovy sestrynskoi spravy [Ethical foundations of nursing]. Medsestrynstvo - Nursing, 2 , 25-27 [in Ukrainian].

9. Zadyraka, L.V. (2016). Osoblyvosti rozvytku profesiino vazhlyvykh psykholohichnykh yakostei maibutnikh medychnykh sester [Features of the development of professionally important psychological qualities of future nurses]. Medsestrynstvo Nursing, 3, 19-22 [in Ukrainian].

\section{ОСОБЕННОСТИ ПРОФЕССИОНАЛЬНОЙ ПОДГОТОВКИ МЕДИЦИНСКИХ СЕСТЕР HА СОВРЕМЕННОМ ЭТАПЕ}

И.Я. Криницкая, М.И. Марущак, И.Н. Клищ

ГВУЗ «Тернопольский государственный медицинский университет имени И.Я. Горбачевского МЗ Украины», г. Тернополь, Украина

Цель: осветить роль медицинских сестер в современной системе здравоохранения и обосновать пути улучшения их профессиональной подготовки.

Материалы и методы. В исследовании использовано библиосемантический и аналитический методы.

Результаты. В статье изложены современные данные о профессиональных и этических качествах медицинской сестры, рефрормировании медсестринства на современном этапе и новых компетенциях в работе среднего медицинского персонала.

Выводы. Без коренного пересмотра всей программы подготовки и переподготовки специалистов сестринского дела, без внедрения новых технологий организации сестринской помощи, материальной и правовой поддержки медицинских сестер дальнейшее совершенствование системы здравоохранения просто невозможно.

КЛЮЧЕВЫЕ СЛОВА: образование; медицинская сестра; реформирование.

\author{
THE FEATURES OF NURSES' PROFESSIONAL TRAINING AT THE PRESENT STAGE \\ I.Ya. Krynytska, M.I. Marushchak, I.M. Klishch \\ I. Horbachevsky Ternopil State Medical University
}

Purpose: to highlight the role of nurses in the modern health system and to justify ways to improve their professional training. 
Materials and Methods. The research used bibliosemantic and analytical methods.

Results. The article presents current data on professional and ethical qualities of a nurse, nursing reform at the present stage and new competencies in the nursing staff work.

Conclusions. Without a radical revision of the whole program of training and retraining of nursing staff, without the introduction of new technologies for the organization of nursing care, material and legal support of nurses, further improvement of the health care system is simply not possible.

KEY WORDS: education; nurse; reform.

Рукопис надійшов до редакції 31.01.2017 р.

\section{Відомості про авторів:}

Криницька Інна Яківна - професор кафедри фрункціональної і лабораторної діагностики ДВНЗ «Тернопільський державний медичний університет імені І.Я. Горбачевського МОЗ України»; тел.: +38(0352) 52-45-54.

Марущак Марія Іванівна - професор, завідувач кафедри функціональної і лабораторної діагностики ДВНЗ «Тернопільський державний медичний університет імені І.Я. Горбачевського МОЗ України»;

тел.: +38(0352) 52-45-54.

Кліщ Іван Миколайович - професор кафедри функціональної і лабораторної діагностики дВНЗ «Тернопільський державний медичний університет імені І.Я. Горбачевського МОЗ України»; тел.: +38(0352) 52-45-54. 